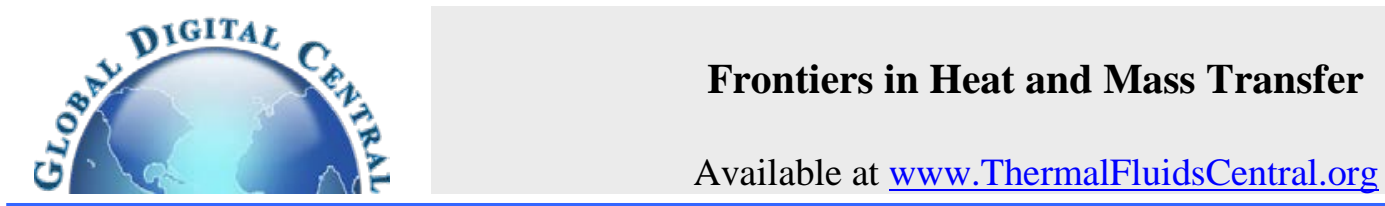

\title{
RESEARCH ON BUILDING GLAZED TILE OF FLY ASH ADDED BY RADIATION HEAT TREATMENT INSIDE CATALYTIC COMBUSTION FURNACE OF NATURAL GAS
}

\author{
Shihong Zhang*, Xu Fan \\ School of Environment and Energy Engineering, Beijing University of Civil Engineering and Arch., Beijing, 100044, China
}

\begin{abstract}
This article discussed compressive strength, water absorption, thermal conductivity and Frost resistance of building glazed tile of fly ash added in order to solve the problem of shortage of raw materials in the production. According to the technology of catalytic combustion furnace, glazed tiles of fly ash added with pure solid texture and glamorous colors were obtained by radiation heat treatment. It also greatly reduced pollutant emissions. The suitable proportion is about $30 \%$ of fly ash from these tests and the molding pressure is $20 \mathrm{MPa}$. The utilization of fly ash not only alleviates the environmental pollution, but also saves raw materials and turns waste into treasure.
\end{abstract}

Keywords: Catalytic combustion furnace; Radiation heat treatment; Building glazed tile; Plain fired pottery with fly ash added.

\section{INTRODUCTION}

Glazed tile as a traditional building component with Chinese characteristics. Widely used in the restoration of ancient buildings, antique buildings, and architectural decoration (Ferrari et al., 2013). The surface enamel can resist the corrosion of harmful gas in the atmosphere and keep the gorgeous color for a long time. And it has high sintering strength, good volume stability and long service life. It can be used for hundreds of years or even thousands of years. These are difficult to achieve with non-sintered materials. However, the traditional production methods of glazed tile have also exposed disadvantages. The first problem is the shortage of raw materials. The high demand for clay in the production has led to its over-exploitation, which has caused damage to cultivated land (Chen et al., 2011). The second is that ceramic furnaces are generally backward in combustion technology, and the emission of smoke pollutants have seriously polluted the environment.

Clay is a material that can withstand high composition fluctuations (Liu et al., 2004). The composition of fly ash is similar to clay. Using fly ash instead of clay is a feasible way to develop green building materials. A considerable effort is being made worldwide on research concerning the reuse of fly ash as a source of alternative raw materials to produce sintered materials. Through experiments, Giuseppe Cultrone et al, found that the textures of the bricks with fly ash were very similar to the textures of those without it, and fly ash bricks show less damage than conventional bricks when exposed to salt crystallization cycles (Cultrone et al., 2009; Da Fonseca et al., 2015). Lingling et al. found that high parameter fly ash can still make brick body have high cold resistance and compressive strength (Lingling et al., 2005). Holanda just changed the forming craft of fly ash brick to overcome the problem of plastic reduction caused by fly ash (Holanda, 2015). This provides solutions for glazed tile which is also a sintered material.

In terms of reducing the emission of pollutants from furnaces, changing the combustion mode can reduce the generation of pollutants fundamentally, avoiding the troubles caused by the secondary treatment of flue gas. As an advanced combustion mode, catalytic combustion plays an extremely important role in improving combustion process, promoting complete combustion and inhibiting the formation of pollutants (Chen et al., 2018). Since 1970s, Pfefferle proposed the concept of catalytic combustion by combining catalytic oxidation with free radical reactions in the gas phase (Pefrrerie and Pefrrerie, 1987). The proposal has received extensive attention. The United States, Japan and other countries have actively carried out research on catalytic technology of gas turbine combustion chamber (Spadaccini et al., 2007; Touchton et al., 1983). Richard Hutter et al. successfully applied catalytic combustion technology to deal with methane in the exhaust gas of lean-burn gas engines (Hutter et al., 2018). Vaillant et al. used metal honeycomb catalyst to design a completely catalytic boiler successful, it shows lower emissions and lower sensitivity to gas qualities (Vaillant et al., 1999).

This experiment is to improve the problems faced by the glazed tile manufacturing industry. The use of advanced catalytic combustion technology to build a catalytic combustion furnace for firing, explore the performance of the furnace and to achieve the purpose of reducing pollution. At the same time, through the use of fly ash, reduce the use of glazed tile raw material clay, to ease the tension of raw materials, to create a good environment and economic benefits.

\section{EXPERIMENTAL SET-UP}

\subsection{Catalytic combustion furnace system}

The natural gas catalytic combustion furnace system is shown in the fig. 1. The body of catalytic combustion furnace is made of stainless steel. For the heat insulation, the inside of the furnace is affixed with $3 \mathrm{~cm}$ thick rock wool. The burner is connected to the left side of the furnace. The exhaust vent is arranged at the bottom right, this ensures that the rising hot air stays in the furnace enough to fully utilize its heat. Thermoelectric thermometers are mounted above through ceramic tubes, the temperature

*Corresponding author. Email: shihongzhang@bucea.edu.cn. 
inside the furnace can be accurately measured. Since the burner is on the side of the furnace. In order to make the object fully heated, a rotating tray is placed inside. Natural gas catalytic burners use premixed combustion. Air is mixed with gas and ignited at the burner head, through frequency converter control fan speed to change the air flow, Fine tune valve to change gas flow, So that the air and gas mix exactly. In order to avoid the backfiring of the burner head caused by overheating, the burner head is cooled by circulating water. The substrate of the catalytic burner in this experiment is honeycomb monolith, the inner surface is coated with active catalyst Pd-Rh.

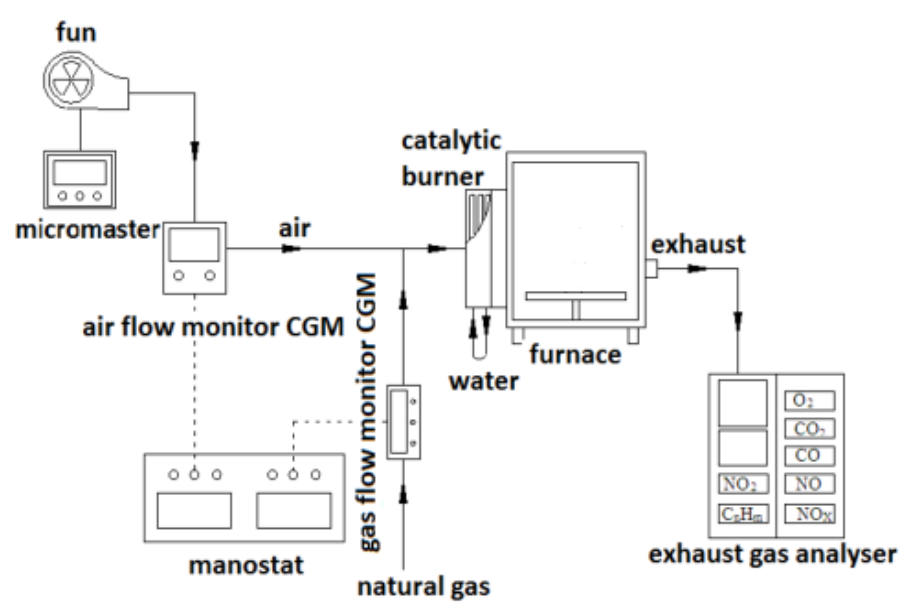

Fig. 1 Catalytic combustion furnace system

\subsection{Raw materials}

The plain fired pottery about glazed tile mainly contained fly ash and clay. The clay was made of raw material "crucible soil". The chemical analysis of clay and fly ash was performed by X-Ray Fluorescence. Their chemical composition was shown in table 1 . The composition of fly ash is basically similar to that of clay. Fly ash is the waste discharged from coal-fired power plants and other furnaces, the content of $\mathrm{SiO}_{2}$ in fly ash is slightly higher than that of clay and the content of alumina $\left(\mathrm{Al}_{2} \mathrm{O}_{3}\right)$ in fly ash is slightly lower than that in clay. The content of other chemical components is basically similar to that of clay.

Table 1 Raw material composition analysis

\begin{tabular}{|c|c|c|c|c|c|c|c|}
\hline Name & $\mathrm{SiO}_{2}$ & $\mathrm{Al}_{2} \mathrm{O}_{3}$ & $\mathrm{Fe}_{2} \mathrm{O}_{3}$ & $\mathrm{CaO}$ & $\mathrm{K}_{2} \mathrm{O}$ & $\mathrm{Na}_{2} \mathrm{O}$ & $\mathrm{MgO}$ \\
\hline $\begin{array}{c}\text { Fly } \\
\text { ash }\end{array}$ & $58.24 \%$ & $27.46 \%$ & $2.86 \%$ & $2.11 \%$ & $1.41 \%$ & $0.35 \%$ & $0.95 \%$ \\
\hline Clay & $55.21 \%$ & $30.02 \%$ & $2.67 \%$ & $1.48 \%$ & $3.37 \%$ & $0.11 \%$ & $1.48 \%$ \\
\hline
\end{tabular}

Because of the poor viscosity of fly ash, the particle size of fly ash must be reduced in order to obtain satisfactory molding effect. However, too small particle size will increase the cost of crushing. It is appropriate that the specific surface area of fly ash is more than $600 \mathrm{~m}^{2} / \mathrm{kg}$ by multiple mixing of mud.

\subsection{Experiments Settings}

The orthogonal test was utilized to investigate the amount of fly ash added as shown in table 2 . There were nine formulations in table 3 . The sample of each formulation needed three copies and water absorption rate and compressive strength were taken as evaluation indicators for orthogonal analysis. They were measured by experiments and the data of the same formula were averaged. Appropriate process obtained through analysis, then the surface of plain fired pottery was glazed. It was baked at about $900{ }^{\circ} \mathrm{C}$ to form glazed tile inside the furnace of catalytic combustion.
Table 2 Factor level table

\begin{tabular}{|c|c|c|c|c|}
\hline LeveX & $\begin{array}{c}\text { Fly ash(a) } \\
\text { /parts }\end{array}$ & $\begin{array}{c}\text { Clay(b } \\
\text { ) } \\
\text { /parts }\end{array}$ & $\begin{array}{c}\text { The forming } \\
\text { pressure(c)/MP } \\
a\end{array}$ & $\begin{array}{c}\text { Sintering } \\
\text { temperature(d } \\
\text { ) }\end{array}$ \\
\hline 1 & 3 & 7 & 10 & 1000 \\
\hline 2 & 4 & 6 & 15 & 1050 \\
\hline 3 & 5 & 5 & 20 & 1100 \\
\hline
\end{tabular}

Table 3 Experimental formulations

\begin{tabular}{|c|c|c|c|c|}
\hline \multirow{2}{*}{$\begin{array}{c}\text { Experiment } \\
\text { number }\end{array}$} & Factor $a$ & Factor $b$ & Factor $c$ & Factor $d$ \\
\cline { 2 - 5 } & Fly ash & Clay & $\begin{array}{c}\text { Molding } \\
\text { pressure }\end{array}$ & $\begin{array}{c}\text { Firing } \\
\text { temperature }\end{array}$ \\
\hline 1 & 1 & 1 & 1 & 1 \\
\hline 2 & 1 & 2 & 2 & 2 \\
\hline 3 & 1 & 3 & 3 & 3 \\
\hline 4 & 2 & 1 & 2 & 3 \\
\hline 5 & 2 & 2 & 3 & 1 \\
\hline 6 & 2 & 3 & 1 & 2 \\
\hline 7 & 3 & 1 & 3 & 2 \\
\hline 8 & 3 & 2 & 1 & 3 \\
\hline 9 & 3 & 3 & 2 & 1 \\
\hline
\end{tabular}

\subsection{Analytical characterization and performance testing}

The temperature of furnace was measured by thermoelectric thermometer to obtain a firing curve. MRU (MGA5) infrared flue gas analyzer was used for exhaust gas analysis. The thermal conductivity was investigated by TC3000 thermal conductivity meter for small size sample of building glazed tile of fly ash added. The compressive strength, water absorption and frost resistance of samples were tested according to Chinese Testing Standard JC /T765 -- 2006 (PRC., 2006).

The frost resistance was tested as following. Ten samples with qualified appearance quality were immersed in clear water for 24 hours. After removing the surface moisture with a dry towel, every sample were put into the freezer that has been reduced to $-20 \pm 3{ }^{\circ} \mathrm{C}$ in advance and refrigerated for 3 hours. Then it was immediately melted in water at 15$20{ }^{\circ} \mathrm{C}$ for 3 hours.

\section{EXPERIMENTAL RESULT AND DISCUSSION}

\subsection{Roasting characteristics of natural gas catalytic combustion furnace}

The temperature change curve inside the furnace was shown in fig. 2. At the time of the ignition we recorded it as zero in the process of experiment. The mixture of nature gas and air was injected, rich enough to achieving a blue flame above the monolith. The blue flame gradually disappeared while the catalyst started glowing red internally. The flow of nature gas was adjusted to the desire lean mixture composition while the catalyst reached steady state as shown in fig. 3.

Due to the adjustment of excess air ratio, the room temperature air volume in lean mixture increased. So that the temperature of furnace had a slight decrease, then the temperature rose slowly again. After that, temperature inside furnace was increased by adjusting aperture of furnace door and input power of the furnace. As the time increases, the temperature rose steeply before reaching $700^{\circ} \mathrm{C}$. After that, there was a slow rise in the temperature. So that slow rise of temperature is the key to ensure that plain fired pottery with mixed fly ash has sufficient time to combine with glaze. 


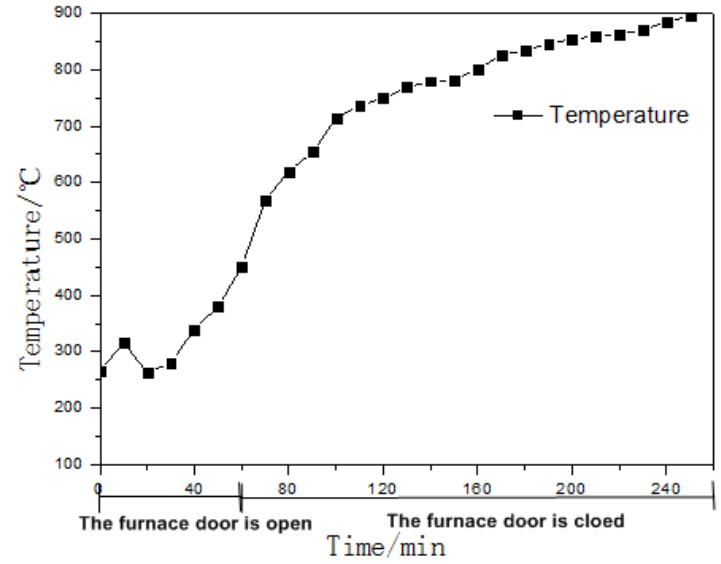

Fig. 2 Diagram of temperature variation over time inside catalytic combustion furnace

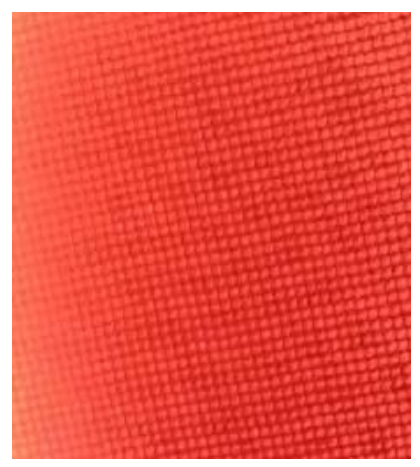

Fig. 3 Steady state of catalytic monolith surface

Radiation heat exchange between the surface of catalytic honeycomb monoliths and the wall surface in an enclosed furnace was regarded as the radiation heat exchange between two gray bodies in an enclosed cavity. It was calculated by Eq. (1),

$$
\phi_{1,2}=\frac{A_{1} \sigma\left(T_{1}^{4}-T_{2}^{4}\right)}{\left(\frac{1}{\varepsilon_{1}}-1\right)+\frac{1}{X_{1,2}}+\frac{A_{1}}{A_{2}}\left(\frac{1}{\varepsilon_{2}}-1\right)}
$$

where $\varepsilon_{1}$ is the emissivity of catalytic honeycomb monoliths surface, which was 0.5 . Its radiation outputs were calculated based on the surface temperatures measured by the infrared pyrometer and using an effective emissivity $\varepsilon_{1}$ of 0.5 . The wall surface is surrounded by heat sink. As the material of wall surface was made up of refractory cotton soil, the emissivity $\varepsilon_{2}$ was $0.85 . X_{1,2}$ is the shape factors, here was $1 . A_{1}$ is the apparent area of the monolith at the open end, which was $A_{1}=$ $0.15 \times 0.3=0.045 \mathrm{~m}^{2}$. The inner casing of furnace still had the shape of a cuboid, whose edges were $370 \mathrm{~mm}$ long, $150 \mathrm{~mm}$ wide and $300 \mathrm{~mm}$ high. $A_{2}$ is the apparent area of the wall surface, which was $A_{2}=0.378$ $\mathrm{m}^{2} . T_{1}$ is the average surface temperature of monoliths, which was 1373 $\mathrm{K} . T_{2}$ is the average temperature of the wall surface, which was recorded approximately as $1173 \mathrm{~K}$ by thermoelectric thermometer. In order to improve the quality of glazed tiles further, the temperature rise rate was strictly controlled during the process of heating. Normally the temperature kept at $900{ }^{\circ} \mathrm{C}$ for twenty minutes. The values of the radiation of the monolith in an enclosed furnace is high (Shihong Zhang et al., 2018).

Fig. 4 plotted exhaust gas pollutant emissions at exhaust sampling point of catalytic combustion furnace vent as time went on. The time of the ignition was also recorded as zero at furnace vent which was connected with pipes of analyzer.

It was revealed that the content of $\mathrm{CH}_{4}$ in gas-phase combustion was measured at about $35 \mathrm{mg} / \mathrm{m}^{3}$. After an interval of 20 minutes $\mathrm{CH}_{4}$ was decreased rapidly with the passage of time.
It was shown that $\mathrm{NO}_{\mathrm{x}}$ rose during the first period of 60 minutes due to the appeared flame influence of gas combustion. Then $\mathrm{NO}$ decreased between 60 and 160minutes. But the emission of $\mathrm{NOx}$ was low (below $20 \mathrm{mg} / \mathrm{m}^{3}$ ) because the exhaust gas had been significantly diluted before the furnace door closed. Then the catalytic combustion entered a steady state gradually with the decreasing $\mathrm{NOx}$ after 60minutes. $\mathrm{NOx}$ dropped to near zero when regulated the flow rate of natural gas to $6.5 \mathrm{~L} / \mathrm{min}$ at 160 minutes, because the temperature is lower than that of the generation of NOx and the oxidation reaction of catalytic combustion is almost complete.

The emission of $\mathrm{CO}$ ascended gradually as time went on during the first period of 110 minutes. The maximum value of $\mathrm{CO}$ is $32 \mathrm{mg} / \mathrm{m}^{3}$. It was clear that the emission of CO was increasing faster after 60 minutes. Because there were $\mathrm{CO}$ selectivities for the fuel-rich concentrations (conditions of partial oxidation) during the start-up process. And CO was not diluted during the furnace door closed after 60 minutes.

The furnace of catalytic honeycomb monolith burner was found possible while preserving near zero emissions after about 180 minutes. The ordinary industrial furnaces need secondary treatment equipment to reach the discharge standard (DB11-501-2017) (PRC., 2017).

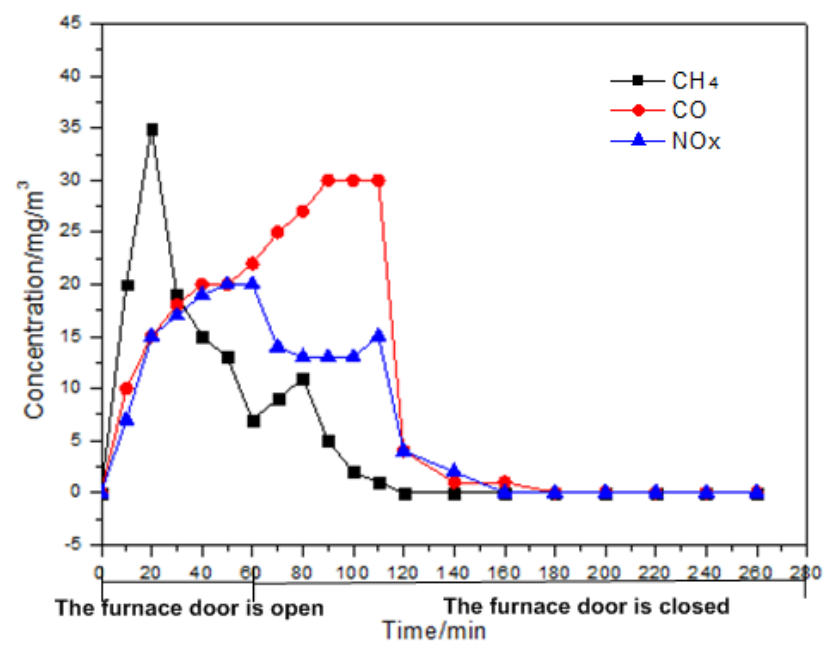

Fig. 4 Curves of emissions in the exhaust gas of catalytic combustion furnace

\subsection{Influence of forming pressure on the properties of plain fired pottery}

The forming pressure can not only make the plain pottery with mixed fly ash have certain shape and strength, but also make the contact between particles close. The diffusion resistance could be reduced during sintering and good for sintering. In the experiment, different forming pressure was used to press the molding. After sintering at $1100{ }^{\circ} \mathrm{C}$ and thermal insulation $30 \mathrm{~min}$, the influence of forming pressure on compressive strength of plain fired pottery was shown in the fig. 5 . The cylindrical samples which were $40 \mathrm{~mm}$ in diameter and $40 \mathrm{~mm}$ in length were semidry pressed by a tableting machine. The ash content of plain fired pottery $(1,2,3)$ was $30 \%, 40 \%, 50 \%$ respectively. When the forming pressure increases from $0 \mathrm{MPa}$ to $5 \mathrm{MPa}$. The compressive strength of plain fired pottery increased gradually. At this time, the plain fired pottery meets the quality standard of MU10. However, the continuous increase of forming pressure has little effect on improving the compressive strength.

If the forming pressure was too large, the elastic aftereffect could cause damage to the plain fired pottery and even the lamellae split as shown in Fig. 6. When the Forming pressure was $40 \mathrm{MPa}$, the plain pottery is damaged, According to summarize by the experiments, the forming pressure should not exceed 20MPa. 


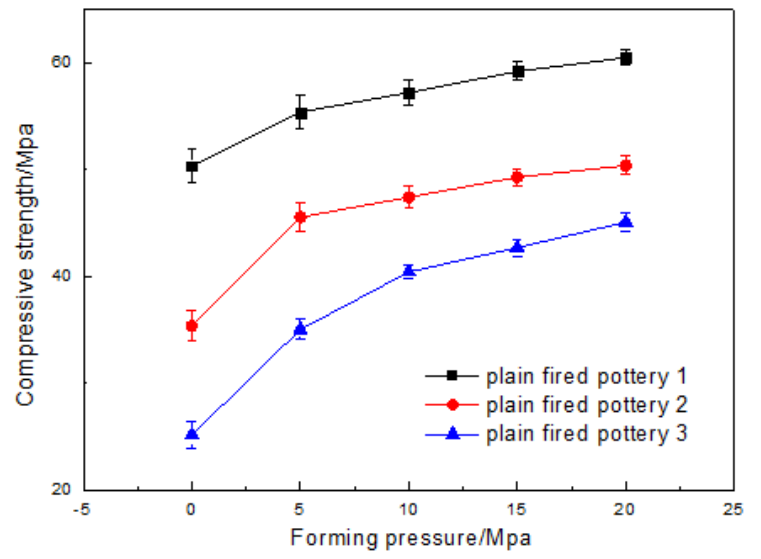

Fig. 5 The compressive strength of plain fired pottery under different forming pressures

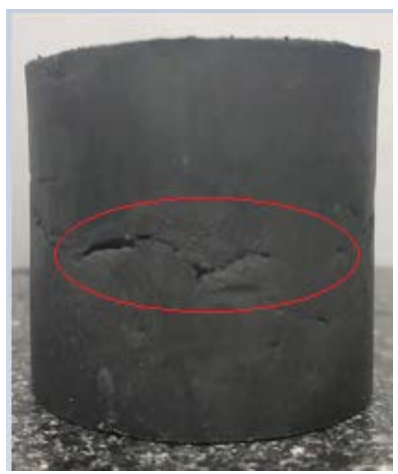

a

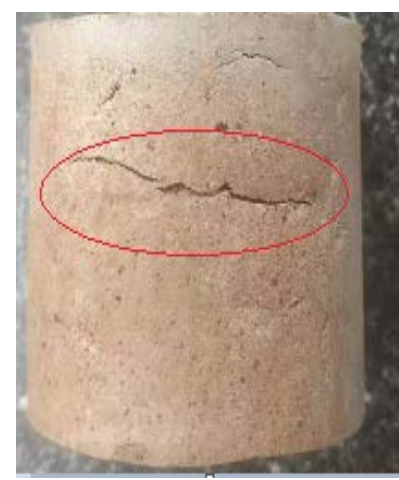

$\beta$
Fig. 6 The plain pottery appears lamellae split ( $a$ ) The plain pottery before sintering

( $\beta$ ) The plain pottery after sintering

\subsection{The influence of various factors on compressive strength and water absorption rate of $5 \mathrm{~h}$}

Factors on influence of compressive strength and water absorption include sintering temperature forming pressure, ratio of fly ash, clay etc. The test data of orthogonal experiments were listed in table 4. The orthogonal experiment is an efficient experimental design method for arranging multi-factor experiments and seeking the optimal level combination. With the increase of the amount of forming pressure and sintering temperature the compressive strength index for plain fired pottery tends to increases and its water absorption decrease.

According to the size of $\mathrm{k}$, the influence of $\mathrm{a}_{1}, \mathrm{a}_{2}$, and $\mathrm{a}_{3}$ on the test index could be judged by the analysis of orthogonal experiments table 4 . The optimized level combination of appropriate formula of various factors was a1, $\mathrm{b}_{1}, \mathrm{c}_{3}, \mathrm{~d}_{3}$. From these tests, the quality fractions of suitable formula were selected as fly ash 3 and clay 7 . The molding pressure was $20 \mathrm{MPa}$ and the sintering temperature of plain fired pottery was about $1100{ }^{\circ} \mathrm{C}$. The compressive strength was more than 60Mpa and water absorption rate was about $9 \%$.

\subsection{Research on thermal conductivity and Frost resistance}

In order to investigating effect on thermal conductivity of plain fired pottery about glazed tile with the amount of fly ash added. The plain fired pottery of common unmixed fly ash was compared with that of optimized level combination of appropriate formula. The thermal conductivity of common plain fired pottery is $0.45 \mathrm{~W} /(\mathrm{m} \cdot \mathrm{K})$ and that thermal conductivity of plain fired pottery with mixed fly ash is $0.39 \mathrm{~W} /(\mathrm{m} \bullet \mathrm{K})$.
The results showed that thermal conductivity of plain fired pottery with mixed fly ash decreased under the condition of the same molding pressure and sintering temperature.

Due to the addition of fly ash, there was less fusible materials in fly ash. It was hard to melt like clay and fill the pores between particles while sintering. Therefore, the formed pores play the role of thermal insulation and heat preservation.

About the freeze-thaw cycle experiment. The results showed that ten samples are in 15 freeze-thaw cycles. There were no cracking, glaze peeling, angle dropping and bulging. It meets the standard of glazed tile products (PRC., 2006) and reaches the condition of superior products.

\section{APPLICATIONS TO THE ARCHITECTURAL DECORATION OF BUILDINGS}

Due to the shortage of raw materials, high energy consumption and serious emission pollution of traditional technology about glazed tile. The samples were brushed with glaze and dried naturally. By the catalytic combustion method and effective substitution of fly ash for raw materials of glazed tile, the production process of building glazed tile has been improved as shown in Fig. 7 and Fig. 8. Heating glazed tiles of fly ash added shows pure solid texture, rich melodic style and glamorous colors. The quality of the finished glazed tile made by catalytic combustion furnace also conforms to the relevant national standards (PRC., 2006). From the perspective of solving environmental pollution and making full use of resources. It provides reference for the transformation and upgrading of glazed tile industry.

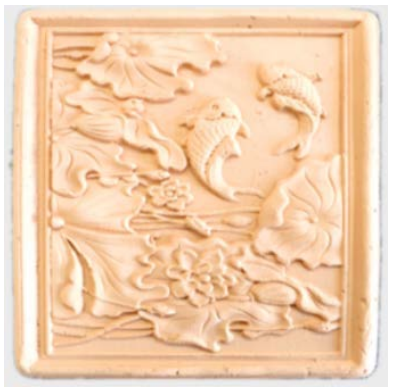

Fig. 7 Plain fired pottery with the amount of fly ash added

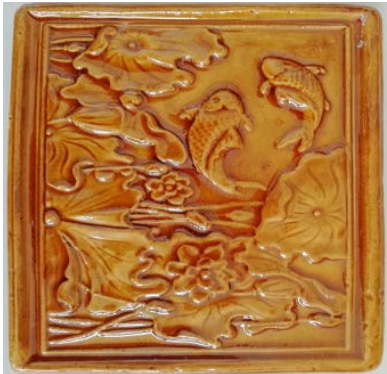

Fig. 8 Building glazed tile of fly ash added

\section{CONCLUSIONS}

The temperature curve could be well controlled inside catalytic combustion furnace in these experiments. Moreover, compared with traditional natural gas, it burnt fully and reduced the concentration of pollutants NOx and CO. The main form of heat transfer inside the furnace is the exchange of heat radiation.

The suitable formula of glazed tile with fly ash added was developed. It is about $30 \%$ fly ash and the forming pressure is $20 \mathrm{Mpa}$. The water absorption rate of the glazed tile body is about $9 \%$, and the compressive strength is more than 60MPa. The thermal stability and frost resistance all reached JC /T765-2006 glazed tile performance standards. The building Glazed tile finished has a smooth appearance, transparent and warm glaze color.

\section{ACKNOWLEDGMENT}

The project was sponsored by the Beijing Municipality Key Lab of Heating Gas Supply Ventilating and Air Conditioning Engineering, Beijing Scholar Program, Key R\&D Project of Ningxia Hui Autonomous Region (2019BFG02016) and the Fundamental Research Funds for Beijing University of Civil Engineering and Architecture. 
Table 4 The $\mathrm{L}_{9}{ }^{(34)}$ of orthogonal experiments

\begin{tabular}{|c|c|c|c|c|c|c|}
\hline \multirow{2}{*}{$\begin{array}{l}\text { Experiment } \\
\text { number }\end{array}$} & Factor a & Factor $b$ & Factor c & Factor d & \multirow{2}{*}{$\begin{array}{l}\text { Water } \\
\text { absorption } \\
\text { rate } / \%\end{array}$} & \multirow{2}{*}{$\begin{array}{c}\begin{array}{c}\text { Compressive } \\
\text { strength }\end{array} \\
(\mathrm{Mpa})\end{array}$} \\
\hline & Fly ash & Clay & $\begin{array}{l}\text { Molding } \\
\text { pressure }\end{array}$ & $\begin{array}{c}\text { Firing } \\
\text { tempera } \\
\text { ture }\end{array}$ & & \\
\hline 1 & 1 & 1 & 1 & 1 & 16.2 & 32 \\
\hline 2 & 1 & 2 & 2 & 2 & 11.6 & 40 \\
\hline 3 & 1 & 3 & 3 & 3 & 9.06 & 65 \\
\hline 4 & 2 & 1 & 2 & 3 & 9.95 & 63 \\
\hline 5 & 2 & 2 & 3 & 1 & 12.06 & 37 \\
\hline 6 & 2 & 3 & 1 & 2 & 17.1 & 29 \\
\hline 7 & 3 & 1 & 3 & 2 & 11.2 & 46 \\
\hline 8 & 3 & 2 & 1 & 3 & 13.8 & 35 \\
\hline 9 & 3 & 3 & 2 & 1 & 20.3 & 26 \\
\hline K1 & 45.667 & 47.000 & 32.000 & 31.667 & & \\
\hline K2 & 43.000 & 37.333 & 43.000 & 38.333 & & \\
\hline K3 & 35.667 & 40.000 & 49.333 & 54.333 & & \\
\hline RangeR1 & 10 & 9.667 & 17.333 & 22.666 & & \\
\hline K4 & 12.287 & 12.450 & 15.700 & 16.187 & & \\
\hline K5 & 13.037 & 12.487 & 13.950 & 13.300 & & \\
\hline K6 & 15.100 & 15.487 & 10.733 & 10.937 & & \\
\hline RangeR2 & 2.831 & 3.037 & 4.927 & 5.250 & & \\
\hline
\end{tabular}

\section{NOMENCLATURE}

$A_{1}$

$A_{2}$

$a$

b

c

$d$

K

$R$

$T_{1}$

$T_{2}$

V

$X_{1,2}$ apparent area of the monolith at the open end $\left(\mathrm{m}^{2}\right)$ apparent area of the wall surface $\left(\mathrm{m}^{2}\right)$

factor of fly ash

factor of clay

factor of forming pressure (MPa )

factor of sintering temperature $\left({ }^{\circ} \mathrm{C}\right.$ )

average value

measures of variation

average surface temperature of monoliths (K)

average temperature of the wall surface $(\mathrm{K})$

natural gas flow rate in burner I $(\mathrm{L} / \mathrm{min})$

shape factors

\section{Greek Symbols}

$\begin{array}{ll}\Phi_{1,2} & 1,2 \text { radiation heat exchange }(\mathrm{kW}) \\ \varepsilon_{1} & \text { emissivity of catalytic honeycomb monoliths surface } \\ \varepsilon_{2} & \text { emissivity of wall surface } \\ \sigma & \text { Stephan-Boltzmann constant }\end{array}$

\section{REFERENCES}

Cultrone G., Sebastián E., 2009, "Fly ash addition in clayey materials to improve the quality of solid bricks," Construction and Building Materials, 23(2), 1178-1184.

https://doi.org/10.1016/j.conbuildmat.2008.07.001

C. M. Spadaccini, J. Peck, I. A. Waitz, 2007, "Catalytic combustion systems for micro-scale gas turbine engines," Journal of Engineering for Gas Turbines and Power, 129(1), 49-60.

https://doi.org/10.1115/1.2204980

Chen, Y., Zhang, Y., Chen, T., Zhao, Y., Bao, S., 2011, "Preparation of eco-friendly construction bricks from hematite tailings," Constr. Build. Mater., 25 (4), 2107-2111.

https://doi.org/10.1016/j.conbuildmat.2010.11.025

Da Fonseca B. S., Galhano C., Seixas D., 2015, “Technical feasibility of reusing coal combustion by-products from a thermoelectric power plant in the manufacture of fired clay bricks,” Applied Clay Science, 104, 189195.

https://doi.org/10.1016/j.clay.2014.11.030

Ferrari, C., Libbra, A., Muscio, A., Siligardi, C., 2013, "Design of ceramic tiles with high solar reflectance through the development of a functional engobe," Ceramics International, 39(8), 9583-9590. https://doi.org/10.1016/j.ceramint.2013.05.077

G.L. Touchton, L. C. Szema, M. B. Cutrone, R. Cellamare, W. Vonkleinsmid, 1983, "Design of a catalytic combustor for heavy-duty gas turbines,” Journal of Engineering for Power, 105(4), 797-805. https://doi.org/10.1115/82-JPGC-GT-24

Holanda J. N. F., 2015, "The properties and durability of clay fly ashbased fired masonry bricks,” Eco-Efficient Masonry Bricks and Blocks. Wood head Publishing: 85-101. https://doi.org/10.1016/B978-1-78242-305-8.00005-X

Hutter, R., De Libero, L., Elbert, P., Onder, C.H., 2018, “Catalytic methane oxidation in the exhaust gas after treatment of a lean-burn natural gas engine,” Chemical Engineering Journal, 349, 156-167. https://doi.org/10.1016/j.cej.2018.05.054

Chen, J., Liu, B., Yan, L., Xu, D., 2018, “Combustion and emissions characteristics of methane-air mixtures in catalytic micro-combustors: a computational fluid dynamics study," Frontiers in Heat and Mass Transfer, 11, 2.

http://dx.doi.org/10.5098/hmt.11.2

Liu, G., Zhang, H., Gao, L., Zheng, L., Peng, Z., 2004, “Petrological and mineralogical characterizations and chemical composition of coal ashes from power plants in Yang zhou mining district, China,” Fuel Process. Technol., 85,1635-1646.

https://doi.org/10.1016/j.fuproc.2003.10.028

Lingling, X., Wei, G., Tao, W., Nanru, Y., 2005, "Study on fired bricks with replacing clay by fly ash in high volume ratio,” Constr. Build. Mater., 19(3), 243-247.

https://doi.org/10.1016/j.conbuildmat.2004.05.017

Pefrrerie, L.D., Pefeffrie, W.C., 1987, "Catalysis in combustion,” Catalysis Reviews-Science and Engineering, 29(2-3), 219-267.

https://doi.org/10.1080/01614948708078071 
PRC, 2006.Building materials industry standard of the People's Republic of China, JC/t765-2006, issued by the National Development and Reform Commission.

PRC, 2017, Beijing municipal standards for the emission of atmospheric pollutants, DB11-501-2017.

Zhang, S., Wei, M., Yang, H., 2018, “Study on Properties of Glazed Tiles Heated by Low-Carbon Catalytic Combustion Furnace of Natural Gas and Applications to Architectural Decoration,” Frontiers in Heat and Mass Transfer, 11, 20.

http://dx.doi.org/10.5098/hmt.11.20

Vaillant S. R., Gastec A. S., 1999, "Catalytic combustion in a domestic natural gas burner,” Catalysis Today, 47(1-4),415-420.

https://doi.org/10.1016/S0920-5861 (98)00324-1 